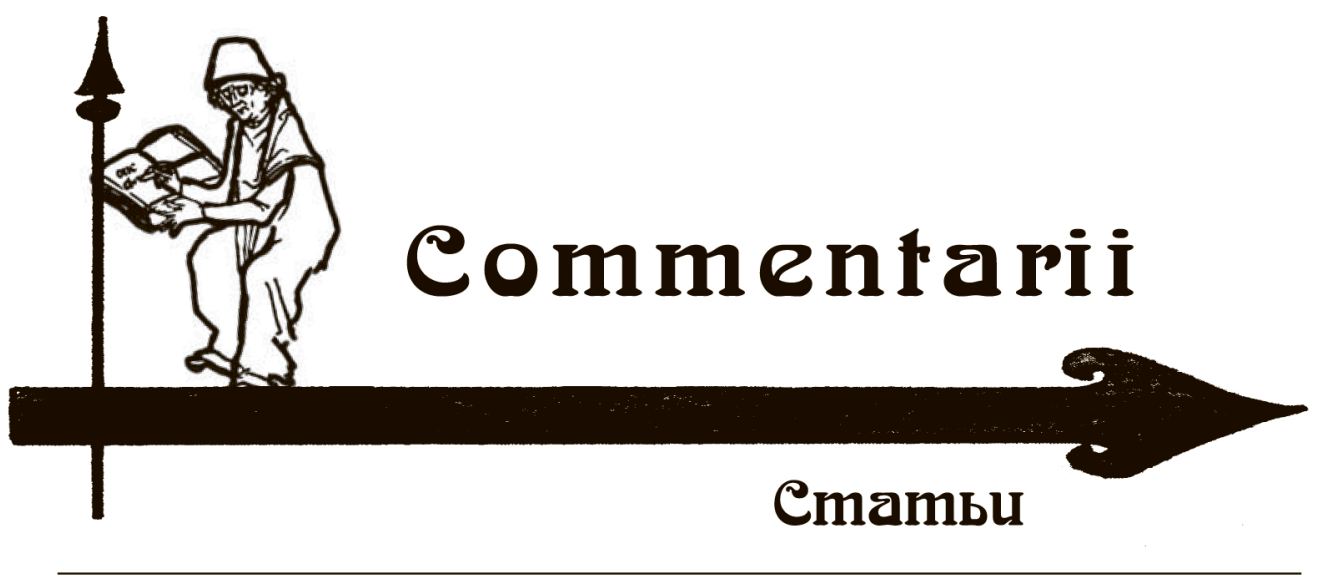

ПРЕЗЕНТАЦИЯ ЛИВОНИИ:

ТЕКСТЫ И ОБРАЗЫ

УДК 94; ББК 63.3 (0); DOI https://doi.org/10.21638/spbu19.2021.101

A. Selart

\title{
LEMBITU: A MEDIEVAL WARLORD IN ESTONIAN CULTURE*
}

The $13^{\text {th }}$ century was undoubtedly a period of upheaval in Baltic history. The crusading conquest of Estonian and Latvian territories resulted in the creation of medieval Livonia, the conglomerate of ecclesiastic states, which for their part perished during the Livonian War in the 1550s and 1560s. From the point of view of modern national historiographies,

${ }^{*}$ The research was supported by the Russian Science Foundation, project Nr. 21-48-04402 «Saints and heroes from Christianization to Nationalism: Symbol, Image, Memory (Nord-West Russia, Baltic and Nordic countries)»

(C) A. Selart, 2021 
the $13^{\text {th }}$-century conquest constitutes the end of the «Estonian» or «Latvian» prehistory and the start of the «German» medieval period ${ }^{1}$.

From the traditional «Estonian» point of view, between 1208 and 1227 ancient Estonians heroically defended their political and personal freedom and native religion, but unfortunately they had to surrender to German invaders and the Catholic Church. This interpretation was adopted by the Estonian audience by the end of the $19^{\text {th }}$ century; after the Estonian War of Independence in 1918-1920, the ancient and modern fights for freedom became combined as the start and finish of the unfortunate intermediate period in the history of the Estonian people ${ }^{2}$. However, there were not many individual historical heroes to find in medieval history who could fit the national narrative. The $13^{\text {th }}$-century sources mention very few Estonians by their names, and in most cases the name of a person is the only information we have. Nevertheless, there is one exception: Lembitu ${ }^{3}$.

The Chronicle of Henry of Livonia ${ }^{4}$, written in the 1220s, refers to Lembitu ${ }^{5}$ (Lembitus, Lembito, Lambito) several times. In 1211, the army from the South Estonian province of Sakala, led by Lembitu and Meme, invaded and devastated the Ymera parish in North Latvia, burning down the church where Henry was the priest ${ }^{6}$. Later on in the same year, the troops of the Crusaders, Livs, and Letts invaded Sakala and located their camp in the village of Lembitu ${ }^{7}$. In 1212, a group of Estonians led by Lembitu killed Catholic priests who missionized Sakala ${ }^{8}$, and then made a rapid raid on Pskov in Rus' ${ }^{9}$. In 1215, the Leole ${ }^{10}$ hillfort of Lembitu surrendered to the Crusaders. Lembitu was baptized and his son or sons were taken

${ }^{1}$ Kaljundi L., Klavinš K. The Chronicler and the Modern World: Henry of Livonia and the Baltic Crusades in the Enlightenment and National Traditions // Crusading and Chronicle Writing on the Medieval Baltic Frontier. A Companion to the Chronicle of Henry of Livonia / Ed. Tamm M., Kaljundi L., Jensen C. S. Farnham, 2011. P. 409-456; Selart A. Historical Legitimacy and Crusade in Livonia // Crusading on the Edge. Ideas and Practice of Crusading in Iberia and the Baltic Region, 1100-1500 / Ed. Nielsen T. K., Fonnesberg-Schmidt I. Turnhout, 2016. P. 29-54; Jensen C. S. Appropriating History. Remembering the Crusades in Latvia and Estonia // Remembering the Crusades and Crusading / Ed. Cassidy-Welch M. London, 2017. P. 231-245; Selart A. 700 Years of Slavery - A View from Estonia // Controversial Histories - Current Views on the Crusades / Ed. Hinz F., Meyer-Hamme J. London, 2021. P. 89-90.

${ }^{2}$ Selart A. Muistne vabadusvõitlus // Vikerkaar. 2003. Nr 10-11. Lk. 108-120. - See also: Tamm M. History as Cultural Memory: Mnemohistory and the Construction of the Estonian Nation // Contested and Shared Places of Memory. History and Politics in North Eastern Europe / Ed. Hackmann J., Lehti M. London, 2020. P. 116-133.

${ }^{3}$ Cf. on Latvia: Misāns I. «Wir waren immer ein Kriegervolk». Die Darstellung der ostbaltischen Kreuzzüge in der lettischen Geschichtsschreibung // Lippe und Livland. Mittelalterliche Herrschaftsbildung im Zeichen der Rose / Ed. Prieur J. Bielefeld, 2008. S. 185-207.

${ }^{4}$ Crusading and Chronicle Writing on the Medieval Baltic Frontier. A Companion to the Chronicle of Henry of Livonia / Ed. Tamm M., Kaljundi L., Jensen C. S. Farnham, 2011.

${ }^{5}$ Oad $K$. Lembitu. Juhtimiskunsti meistriklass vastsel Maarjamaal // Acta Historica Tallinnensia. 2017. Kd. 23. Lk. 26-48.

${ }^{6}$ Heinrici Chronicon Livoniae / Ed. Arbusow L., Bauer A. Hannover, 1955. S. 86. § XIV.12.

${ }^{7}$ Heinrici Chronicon Livoniae. S. 94. § XV.7.

${ }^{8}$ Heinrici Chronicon Livoniae. S. 99. § XV.9.

${ }^{9}$ Heinrici Chronicon Livoniae. S. 100. § XV.10.

${ }^{10}$ Most probably modern Lõhavere (Tõnisson E. Eesti muinaslinnad / Ed. Mäesalu A., Valk H. Tartu, 2008. Lk. 271-273). 
hostage ${ }^{11}$. The agreement did not last, the war started again, and in 1217 the Estonian army led by Lembitu and the army of Germans, Livs, and Letts met on 21 September near Viljandi ${ }^{12}$. The Estonians were defeated, and Lettish noble Veko «recognized Lembitu, pursued him, and killed him. Veko took his garments, and the rest cut off his head and brought it back to Livonia with them ${ }^{13}$. Leole as a political centre ceased to exist and gave way to the SuureJaani church and parish centre nearby.

Obviously, Lembitu became the Estonian historical hero. Numerous artistic presentations have popularised his person and shaped the public image of Lembitu as a king-like leader of the resistance in the name of freedom and independence. He received manifold cultural representations, through decades and changing political circumstances. Friedrich Reinhold Kreutzwald (1803-1882), the author of the Estonian national epic «Kalevipoeg», also composed the epic poem «Lembitu» $(1885)^{14}$, a free adaptation of «Buddha» by Swiss author Joseph Victor Widmann (1842-1911). Several other authors portrayed Lembitu ${ }^{15}$, most influentially, probably, Karl August Hindrey (1875-1947) in his novel «Lembitu» (1938), and Mait Metsanurk (1879-1957) with the novel «At the Ümera River» (1934). In the latter, Lembitu, albeit a secondary figure in the narrative, is portrayed as a far-sighted, respected, and maybe even authoritarian politician and war leader ${ }^{16}$. The final chapters of the book by Hindrey describe the fate of Lembitu's severed head: his son, a hostage in Riga, saves the head and cremates it according to the ancient rites ${ }^{17}$. Unsurprisingly, even the first Estonian (short) opera in 1908 was «The Daughter of Lembitu» (Lembitu tütar) by Artur Lemba (1885-1963) ${ }^{18}$. Another «Lembitu» opera was composed by Villem Kapp (1913-1964), premiering in 1961 ${ }^{19}$. It is worth mentioning that Villem Kapp was a native of Suure-Jaani.

In Estonian visual arts, the person of Lembitu had to connect the ancient and modern freedom of Estonia. Sculptor Amandus Adamson (1855-1929), who had planned an equestrian statue of Lembitu in 1919-1921, some years later materialised the monument of the Estonian War of Independence in Suure-Jaani, in the «home parish» of Lembitu ${ }^{20}$. It depicts Lembitu wounded and has two dates engraved, 1217 and 1918-192021, connecting in this way symbolically the wars of the $13^{\text {th }}$ and $20^{\text {th }}$ centuries $^{22}$. After the Soviet conquest of Estonia, Lembitu

${ }^{11}$ Heinrici Chronicon Livoniae. S. 120. § XVIII.7; S. 122. § XIX.1.

${ }^{12}$ Heinrici Chronicon Livoniae. S. 141-143. § XXI.2-3; S. 180. § XXV.2.

${ }^{13}$ The Chronicle of Henry of Livonia / Transl. Brundage J. A. New York, 2003. P. 162.

${ }^{14}$ Kreutzwald Fr. R. Lembitu. Kreutzwaldi usulis-filosoofiline maailmavaade. Friedrich Reinhold Kreutzwald 200 / Ed. Sutrop U. Tallinn, 2003.

${ }^{15}$ Kalda M. Lembitu kuldne karikas // Looming. 2003. Nr 12. Lk. 1882-1894.

${ }^{16}$ Metsanurk M. Ümera jõel. Tallinn, 2008. Lk. 255-268.

${ }^{17}$ Hindrey K. A. Loojak II: Lembitu. Tartu, 1938. Lk. 187.

${ }_{18}$ The first version of the music by Lemba composed a few years earlier, based on the poem «Sabina» (1859) by Russian poet Afanasy Fet (1820-1892) (Hirvesoo A. Esimese rahvusooperi tulek meie lavale // Teater, Muusika, Kino. 1986. Nr 8. Lk. 69-75).

${ }^{19}$ Tõnson H. Villem Kapp. Tallinn, 1967. Lk. 117-131.

${ }^{20}$ Kaljundi L., Kreem T.-M. Ajalugu pildis — pilt ajaloos. Rahvuslik ja rahvusülene minevik eesti kunstis. Tallinn, 2018. Lk. 174-181.

${ }^{21}$ The monument was opened in 1926, destroyed by the Soviets in 1941, restored during the German occupation in 1942, destroyed again during the second Soviet occupation in 1950, and restored again in 1990.

${ }^{22}$ Kaljundi L., Kreem T.-M. Ajalugu pildis... Lk. 76, 321. 
as depicted in art began to fuse with the mythological Kalevipoeg in the 1940s and 1950s, both fighting against the Teutonic knights — «Germans» — now ${ }^{23}$.

After 1850, the propaganda of «Lembit» as an Estonian native male name began, and the peak of its popularity remains in the 1930 s and $1940 \mathrm{~s}^{24}$. The first vessel of the freshly established Estonian navy in 1918 - expectedly — received the name «Lembit» (formerly «Bobr» of the Russian imperial navy $)^{25}$. «Lembit» was the name of one of the two submarines built in England for Estonia in 1935-1937. Remarkably, the other one was «Kalev» — thus, the names of the real historical person and mythological hero stood on the same level. The decision on the submarine names was personally made in March 1936 by the commanderin-chief of the Estonian armed forces, Johan Laidoner (1884-1953) ${ }^{26}$, and it fit well with the naming traditions of Estonian military vessels of the interwar period, which preferred names both from mythology and deeper history.

It is noteworthy that when the «Lembit» submarine was taken over by the Soviet navy in 1940, it preserved its name - most probably due to its obvious anti-German connotations. Lembit(u) was the name of the Second World War Soviet Army tank group (1945), a garment factory in Tallinn (1961), and the name of several streets, parks, cinemas, and even kolkhozes. In the Estonian toponymy of the Soviet period, the Lembitu name was possibly a way to avoid locally the use of names of Russian or communist heroes directly allegiant to the regime. Estonian writer Juhan Smuul (1922-1971), however, noted ironically in the 1960 s that «Tallinn fashion house got the name of the first Estonian polkovnik who fell in the Assamalla ${ }^{27}$ battle $\rangle^{28}$. The same garment factory name issue was sarcastically addressed in 1974 by stage director Voldemar Panso (1920-1977), who briefly added regarding the theatre presentations of Lembitu: «Only a favourable personality, buckles (of the costume. $-A$. $S$.), and hundred kilograms (weight of the actor. - A. S.)» ${ }^{29}$. «The thinking routine (which derives from the $19^{\text {th }}$ century. $-A$. S.) and theatre-dusty black-and-white primitive technique stop our original ideas ${ }^{30}$.

This was first of all an ironic reflection of the Soviet naming policy, but also a turn towards more playful treatment of the person of Lembitu and his heroic historical role. Decades later, when the perestroika era also popularised every kind of esotericism, the Estonian youth magazine «Noorus» published in 1991 a detailed description of Lembitu and his life by «medium Viktor» (Viktor Tõnissoo, 1931-2010) ${ }^{31}$. In the best-selling novel «Rehepapp ehk November» («Old Barny, or November», 2000) by Andrus Kivirähk, an ironic insight into popular presentations of the Estonian «national character», a manor house valet legitimises his thefts: Lembitu, the king of Estonians, was ignobly murdered by ancestors of German manorial lords; «Despite everything, I am the successor of the Estonians' king Lembitu, and consequently, the

${ }^{23}$ Kaljundi L., Kreem T.-M. Ajalugu pildis... Lk. 108-109, 148-150, 336.

${ }^{24}$ Rajandi E. Raamat nimedest. Tallinn, 1966. Lk. 106-108.

${ }^{25}$ Dunn S. R. Battle in the Baltic. The Royal Navy and the Fight to Save Estonia \& Latvia 1918-20. Barnsley, 2020. P. 62.

${ }^{26}$ National Archives of Estonia. ERA.2553.1.2. Sõjavägede ülemjuhataja päevaraamat 1934-1938. Lehed 94-95.

${ }^{27}$ Assamalla battle - mythological battle mentioned in the «Kalevipoeg».

${ }^{28}$ Smuul J. Muhu monoloogid. Polkovniku lesk. Tallinn, 1968. Lk. 127.

${ }^{29}$ Panso $V$. Portreed minus ja minu ümber. Tallinn, 1975. Lk. 184.

${ }^{30}$ Panso $V$. Portreed minus... Lk. 188-189.

${ }^{31}$ Maiberg T. Uskuda või mitte? // Noorus. 1991. Nr 6. Lk. 29, 32. 
underpants of the baron belong to me! $\rangle^{32}$ In this way, the topic of historical injustice in the Estonian past received an explicitly absurd presentation. The most significant indication of changing attitudes towards the heroisation of $13^{\text {th }}$-century history was the movie «Malev» («Men at Arms», 2005), authored by «Õ-Fraktsioon». The latter is a creative community established in ca. 2000 by a group of University of Tartu students of the political sciences. «Malev», a semi-professionally produced comedy, uses a method that exaggerates the stereotypic presentations of Estonian past into absurdity ${ }^{33}$. Lembitu, played by actor Ain Mäeots, is a true, stereotypical «ancient Estonian» there: fair-haired and uncombed, he spends his time singing, dancing, and practising the ius primae noctis, and goes into battle against German knights with his war-cow and gigantic box zither.

A new turn in the presentations of Lembitu in Estonian media happened in the 2010s. The topic then became connected to a perhaps unexpected and certainly an odd issue - the fate of the skull of the medieval warlord. Namely, in Estonia in the 1960s, a report began to circulate that somewhere in Poland the head of Lembitu still existed. As it often happens in the case of these kinds of reports, there are at least two versions about the origin of the story.

One of them is connected to the Estonian man of letters, Aleksander Kurtna (1914-1983) ${ }^{34}$. After completing his secondary school education in 1932, he studied in Petseri Orthodox Theological Seminary. After conversion to Catholicism, Kurtna left Estonia and continued his studies in 1935 in the Papal Eastern Seminary in Dubno, then Poland. A bit later, Kurtna proceeded to Rome and spent 1936-1940 at the Gregorian University and in the Collegium Russicum. He also started historical research at the Vatican archives, receiving from the Estonian state a scholarship for this purpose, and graduated from the Vatican School of Paleography, Diplomatics and Archivistics in 1944. After visiting Estonia and Moscow during late summer and autumn of 1940, when Estonia was already occupied by the Soviet Union, he was able to return to Rome, but very probably from then on at the latest as a Soviet agent. In 1942, Kurtna simultaneously started cooperation with the German intelligence in Rome. Arrested by British and American counterintelligence officers in 1944, he was released into Soviet custody and transported to Moscow $^{35}$. After years in the GULAG in 1945-1954, Kurtna returned to Estonia, where he became polyglot translator of belles-lettres and a central figure in Estonian cultural life. He was particularly eminent in his role as a translator of Polish literature.

Allegedly, Aleksander Kurtna reported ${ }^{36}$ that somewhere in Poland he had seen a medieval skull of Estonian origin. After his time in Dubno, Kurtna visited Poland several times, both

\footnotetext{
${ }^{32}$ Kivirähk A. Rehepapp ehk november. Tallinn, 2006. Lk. 76.

${ }^{33}$ Kaljundi L. Malev// Forschungen zur baltischen Geschichte. 2007. Bd 2. S. 219-225; Mazierska E. Postsotsialistlik Eesti filmikunst kui rahvusülene kino // Kunstiteaduslikke Uurimusi. 2011. Nr 3-4. Lk. 166-191 (here lk. 169-172).

${ }^{34}$ Kivimäe J. Aleksander Kurtna ja Eesti Teaduste Akadeemia // 50 aastat Eesti Teaduste Akadeemiat / Ed. Köörna A. et al. Tallinn, 1989. Lk. 187-190.

${ }^{35}$ Graham R. A. Un agente sovietico in Vaticano. La leggenda di «don» Alessandro Kurtna // Studium. 1981. Vol. 77. P. 11-24; Alvarez D. Spies in the Vatican. Espionage and Intrigue from Napoleon to the Holocaust. Lawrence (KS), 2002. P. 224-236; Alvarez D., Graham R. A. Nothing sacred. Nazi espionage against the Vatican 1939-1945. London, 2003. P. 117-135; Добровольская Ю. А. Post Scriptum: Вместо мемуаров. СПб., 2006. С. 131-133; Erelt P. Surnud luuraja tagasitulek. Spioonilugusid Eestist ja eestlastest. Tallinn, 2013. Lk. 125-134; Schütz E. Alma Kurtna. Unustamatu lauluõpetaja. Tartu, 2018. Lk. 42-59.

${ }^{36}$ Kärmas M. Eesti ja Poola ülikoolid uurivad legendi Lembitu pea kohta, 20.09.2017. URL: https://www. err.ee/619687/eesti-ja-poola-ulikoolid-uurivad-legendi-lembitu-pea-kohta (last visited — 01.06.2021).
} 
before, during, and after the World War ${ }^{37}$. Thus, he potentially had the possibility to see the item somewhere - if it really exists or existed, indeed.

An alternative version tells about a group of Polish art students (or artists, or museum employees) who visited Estonia at some point in the 1950s and told a story about a skull in some Polish museum, labelled as Caput Duci[s] Estoniae or Rex Estoniae. Most likely, the origin of this information ${ }^{38}$ in Estonia goes back to Voldemar Miller (1911-2006) ${ }^{39}$. Miller, a historian, bibliographer, archivist, and children's author, worked in 1937-1950 in the archive in Tartu. To avoid political arrest, he laboured in 1950-1952 as a miner in oil shale production in North-East Estonia. In 1952, Miller became a staff member of the Library of the Academy of Sciences of the Estonian SSR in Tallinn. Several memoirs indicate Miller as the teller of the story about the skull ${ }^{40}$.

Estonian historian Enn Tarvel had the possibility to visit Poland and tried to check the facts behind the story already in 1969 , but without any success ${ }^{41}$. The tale continued to circulate during the following decades, but mostly in the academic environment ${ }^{42}$. Only the popularising monograph about the $13^{\text {th }}$-century conquest of Estonia by Mart Helme which mentioned the fable in $2010^{43}$ made it more broadly familiar. Hillar Sein, then a functionary in the Estonian Ministry of Culture and himself a native of Suure-Jaani parish, initiated in 2014 contact between the Estonian and Polish ministries of culture, which resulted in some investigations in Polish museums with the aim of locating the artefact ${ }^{44}$. The initiative was renewed in 2017, and in 2018-2019 the Estonian Ministry of Culture funded the research of Estonica in Poland with 10,000 euros ${ }^{45}$.

Is the story about the skull just an urban legend? In the Middle Ages, removing the head of a defeated enemy as a sign of victory was not an uncommon practice ${ }^{46}$. Even in the case of the Russian Emperor Nicholas II (1868-1918), the tale exists that after the execution in Yekaterinburg his head was removed and taken to the Moscow Kremlin ${ }^{47}$. However, in the case of the «skull of Lembitu», the main — and actually the only — argument for the reliability of the story is that the head is allegedly located in Poland. In the mid- $16^{\text {th }}$ century, when the

${ }^{37}$ Graham R. A. Un agente sovietico in Vaticano... P. 13; Alvarez D., Graham R. A. Nothing sacred... P. 118; Eesti Kirjandusmuuseum. EKLA f. 299 s. m29:13: Poola RV-i sõidu avaldus ja ankeet [1968, 1970].

${ }^{38}$ Erelt P. Poolas otsitakse eestlaste kuninga Lembitu pealuud // Eesti Ekspress. 06.09.2017. Nr 36 (1448). Lk. 7; Kärmas M. Eesti ja Poola ülikoolid...

${ }^{39}$ Pillak P. Voldemar Miller 90 // Tuna. Ajalookultuuri ajakiri. 2001. Nr 2. Lk. 121-128.

${ }^{40}$ Kärmas $M$. Eesti ja Poola ülikoolid...

${ }^{41}$ Kärmas M. Eesti ja Poola ülikoolid...

${ }^{42}$ Cf.: Vedler S. Kus asub Lembitu pealuu? // Eesti Ekspress. 28.04.2005. Nr 17 (803). Lk. A 11.

${ }^{43}$ Helme M. Lembitu. Eesti kroonimata kuningas. Tallinn, 2010. Lk. 136-137.

${ }^{44}$ Erelt P. Poolas otsitakse... Lk. 7; Priks $\ddot{U}$. Kas Lembitu pea on poolakate käes? // Sakala. 04.02.2021. Nr 23. Lk. 9; Kärmas M. Eesti ja Poola ülikoolid...

${ }^{45}$ Himma M. Kultuuriministeerium toetab Lembitu pealuu otsinguid 10000 euroga, 24.01.2018. URL: https://novaator.err.ee/676986/kultuuriministeerium-toetab-lembitu-pealuu-otsinguid-10-000euroga (last visited - 01.06.2021).

${ }^{46}$ Schmitz-Esser R. Der Leichnam im Mittelalter. Einbalsamierung, Verbrennung und die kulturelle Konstruktion des Körpers. Ostfildern, 2016. Lk. 641-644.

${ }^{47}$ Бегунов Ю. Участь царской головы. Следы ведут в Кремль // За русское дело. 1996. № 2 (34). C. 1, 7. 
post-medieval Livonia collapsed, the Archbishopric of Riga and the Teutonic Order in Livonia were secularised and became subjects of the Polish-Lithuanian state. A large number of historical materials, including the documents from the archive of the $\operatorname{archbishopric}^{48}$, were removed to Poland. As a result, Poland really is the country where one can discover medieval and early modern Livonica unknown until now ${ }^{49}$. When the story about the skull was just invented, its author(s) would have been well familiar with the history of Livonia and Livonian historical records. Nevertheless, the episode with the head of Lembitu could have been familiar also to a broader audience than professional historians. Although the Estonian translation of the Chronicle of Henry was outdated ${ }^{50}$ and had only very limited circulation in the 1950 s and $1960 \mathrm{~s}^{51}$, the story about the severed head of Lembitu had been told by Hindrey ${ }^{52}$ and briefly mentioned in several popular history books as well ${ }^{53}$.

Although the aim of the research of Estonica or Livonica in Poland that was funded by the Estonian state was defined broadly and had real scholarly results ${ }^{54}$, for the media and public audience it was definitely the project «searching for the skull of Lembitu». It provided material for humourists ${ }^{55}$, as well as for uncomfortable questions about the (in)appropriate use of money requested from politicians ${ }^{56}$. The topic was also exploited sometimes in an unexpected way by journalists and politicians. Left-wing columnist Ahto Lobjakas, after demonstrating his very limited knowledge about the scholarly understanding of Estonian history, feared that if the skull would be discovered, the members of the Estonian political and cultural elite would use the DNA data to measure their proximity to Lembitu and start to create some kind of blood-based aristocracy, «although he [Lembitu] was just a random

${ }^{48}$ Götz J. Das Archiv des livländischen Deutschordenszweiges. Eine archivgeschichtliche Untersuchung // Die Kirche im mittelalterlichen Livland / Ed. Biskup R. et al. Toruń, 2019. P. 9-77 (here p. 10).

${ }^{49}$ Tarvel E. 1) Estica Vanade Aktide Peaarhiivis Varssavis // Eesti NSV Teaduste Akadeemia Toimetised. Ühiskonnateaduste seeria. 1960. Kd. 9. Lk. 292-304; 2) Estonica’t Poola arhiivides ja raamatukogudes // Eesti NSV Teaduste Akadeemia Toimetised. Ühiskonnateaduste seeria. 1972. Kd. 21. Lk. 152-162.

${ }^{50}$ Läti Hendriku Liiwi maa kroonika ehk Aja raamat / Transl. Jung J. Tartu, 1881-1884.

${ }^{51}$ The translation published in exile was not publicly available in the Soviet Union (Henriku Liivimaa kroonika / Transl. Mägiste J. Stockholm, 1962). The situation changed only in the 1980s (Henriku Liivimaa kroonika / Transl. Kleis R. Tallinn, 1982).

${ }^{52}$ See also: Kalda M. Lembitu kuldne karikas. Lk. 1888-1894.

${ }^{53}$ Luiga J. Lembitu surm // Eesti Kirjandus. 1921. Kd. 15. Lk. 106-115 (here lk. 106); Kruus H. Eesti ajaloo lugemik. Kd. 1. Valitud lugemispalad Eesti ajaloo alalt 1561. aastani. Tartu, 1924. Lk. 31; Eesti ajalugu. Kd. 1: Esiajalugu ja Muistne vabadusvõitlus / Ed. Moora H., Kruus H. Tartu, 1935. Lk. 320; Eesti NSV ajalugu. Kd. 1: Kõige vanemast ajast XIX sajandi 50-ndate aastateni / Ed. Naan G., Vassar A. Tallinn, 1955. Lk. 139; Eesti NSV ajaloo lugemik. Kd. 1 / Ed. Kahk J., Vassar A. Tallinn, 1960. Lk. 34; Tõnisson E. et al. Kui Lembitu kutsus... Tallinn, 1968. Lk. 81. ${ }^{54}$ Selart A., Mäesalu M. Die estnischen Kopfjäger in Polen. Eine Archivreise // Forschungen zur baltischen Geschichte. 2019. Bd 14. S. 197-205.

${ }_{55}^{5}$ Juur M. Kuningas Lembitu tagasitulek // Postimees. Arvamus / kultuur. 03.02.2018. Nr 455. Lk. 12; Poolast leiti Lembitu pealuu // Eesti Ekspress. 01.04.2020. Nr 14 (1582). Lk. 6.

${ }^{56}$ Kuula järele: peaministri ülevaade arengutest Lembitu pealuu otsimisel, 01.01.2019. URL: https://www.err.ee/888857/kuula-jarele-peaministri-ulevaade-arengutest-lembitu-pealuu-otsimisel (last visited - 01.06.2021). 
warlord from the periphery ${ }^{57}$. Most probably, he had taken the topic of DNA relatives of Lembitu from the parody by historian Kaarel Vanamölder, a fantasy of what would happen in Estonia when the skull would be discovered ${ }^{58}$. Anyway, the subject had entered the media to remain there. In December 2020, the liberal opposition in the Estonian Parliament began a massive obstruction campaign to stop a referendum about the heterosexual-only definition of marriage, proposed by the government. The opposition members presented almost 10,000 alternative referendum questions, often of an absurd or irrelevant nature. Parliament member Jaak Juske of the Social Democratic Party, himself a history teacher and creditable populariser of history, proposed 57 versions of questions for the public referendum, mostly about history, including «Does the skull of Lembitu exist?» ${ }^{59}$.

All in all, the «skull of Lembitu» has become a catchphrase used in both relevant and irrelevant $\operatorname{cases}^{60}$. Journalist Andrei Hvostov hyperbolised some years ago already that some traditionalist views on medieval Estonian history could only find proof after directly connecting to Lembitu in some esoteric way, but «We reached the Age of Aquarius, where the New Age rules and paranormal sciences spread. There is no need to be ashamed of or deny belonging to this camp ${ }^{61}$. The public need for a historical hero, local patriotism combined with tourism marketing ${ }^{62}$, and at least during the last decades the playful handling of history or historical stereotypes shape in combination the presentations of Lembitu in Estonian media and culture today.

Информация о статье

Исследование выполнено при поддержке РНФ, проект № 21-48-04402 «Святые и герои: От христианизации к национализму. Символ, Образ, Память (Северо-Западная Россия, страны Балтии и Северной Европы)»

Автор: Селарт, Анти — доктор философии, профессор, Университет Тарту, Тарту, Эстония; приглашенный исследователь, Институт истории, Санкт-Петербургский государственный университет, Санкт-Петербург, Россия, Orc ID 0000-0001-8608-9154; e-mail: anti.selart@ut.ee

Заголовок: Lembitu: A medieval warlord in Estonian culture [Лембит — средневековый вождь в эстонской культуре]

Резюме: Тринадцатый век был периодом великих перемен в Балтийской истории. С традиционной для эстонской историографии точки зрения, в 1208-1227 гг. древние эстонцы героически защищали свою политическую и личную свободу и автохтонную религию, но им пришлось признать господство немецких захватчиков и католической церкви. Эта интерпретация стала среди эстонской аудитории преобладающей к концу XIX века. В то же время в эстонском нарративе существовал дефицит

${ }^{57}$ Lobjakas A. Lembitu kolp ja valju saatuse nooled / Lääne Elu. Nr 12. 30 jaanuar 2018. Lk. 2.

${ }^{58}$ Vanamölder K. Lembitu pealuu on leitud! Stsenaariumivisand olukorra puhuks, kui Sakala kuninga pealuu Poolast üles leitakse // Sirp. Eesti kultuurileht. 03.02.2018. Nr 5 (3676). Lk. 10-11. ${ }^{59}$ Juske J. Muudatusettepanekud Riigikogu otsuse «Rahvahääletuse korraldamine abielu mõsite küsimuses» eelnõule (288 OE). URL: https://www.riigikogu.ee/download/9728992e-689e-444b9d13-1fc937b905d5 (last visited - 03.03.2021).

${ }^{60}$ For example: Helme Pätsi monumendi võidutööst: see meenutab Lembitu pea maharaiumist, 01.07.2020. URL: https://www.err.ee/1107841/helme-patsi-monumendi-voidutoost-see-meenutablembitu-pea-maharaiumist (last visited - 04.03.2021).

${ }^{61}$ Hvostov A. Kureperspektiivi põlastamine ehk Kes on sündinud roomama, see ei hakka lendama // Sirp. Eesti kultuurileht. 05.04.2013. Nr 14 (3436). Lk. 4-5.

${ }^{62}$ Kenk $O$. Galerii ja video: Suve mastaapseim vabaõhuetendus hargneb Lõhavere linnamäel, 15.08.2017. URL: https://kultuur.err.ee/613153/galerii-ja-video-suve-mastaapseimvabaohuetendus-hargneb-lohavere-linnamael (last visited - 04.03.2021). 
исторических героев, источники ХІІІ в. зафиксировали очень немного имен эстонцев. Существует одно исключение - Лембит - вождь северной части территории Сакала. В 1217 г. он был убит в бою с крестоносцами. Как сообщает современная хроника, голова Лембита была отрезана и забрана победителями. В XIX-XX вв. создавались многочисленные художественные образы Лембита. Это способствовало популяризации образа народного героя, схожего с образом короля, борющегося за свободу и независимость. В начале 2000 -х гг. получило развитие ироничное или критическое отношение к традиционному образу Лембита. Новое обращение к образу национального героя в эстонском медиапространстве произошло в 2010-х гг. и было связано с вопросом о судьбе черепа лидера древней Сакалы. Еще в 1960-х гг. в Эстонии стали распространяться сообщения о том, что где-то в Польше находится голова Лембита. В 2014 г. Министерства культуры Эстонии и Польши инициировали поиск артефакта в польских музеях. В 2018-2019 гг. Министерство культуры Эстонии финансировало научный проект по поиску и изучению источников по эстонской истории в Польше. Не смотря на то, что цели исследования были определены достаточно широко, в средствах массовой информации и среди общественности проект воспринимался как «Поиск черепа Лембита». Сегодня в культуре и медиа сфере Эстонии обращение к образу Лембита и его презентация определяются такими факторами как потребность общества в наличии собственного национального исторического персонажа, локальный патриотизм, развитие туризма и обыгрывание исторических сюжетов в туристических объектах.

Ключевые слова: средневековье, исследования средневековья, средневековая Ливония, эстонская историография, историческая имагология, исследование культуры

Литература, использованная в статье:

Добровольская, Юлия Абрамовна. Post Scriptum: вместо мемуаров. Санкт-Петербург: Алетейя, 2006. $316 \mathrm{c}$.

Alvarez, David; Graham Robert A. Nothing sacred. Nazi espionage against the Vatican 1939-1945. London: Frank Cass, 2003. 190 p.

Alvarez, David. Spies in the Vatican. Espionage and Intrigue from Napoleon to the Holocaust. Lawrence, KS: University Press of Kansas, 2002. 341 p.

Crusading and Chronicle Writing on the Medieval Baltic Frontier. A Companion to the Chronicle of Henry of Livonia / Ed. Tamm, Marek; Kaljundi, Linda; Jensen, Carsten Selch. Farnham: Ashgate, 2011. 487 p.

Dunn, Steve R. Battle in the Baltic. The Royal Navy and the Fight to Save Estonia \& Latvia 1918-1920. Barnsley: Seaforth, 2020. 304 p.

Eesti ajalugu. Kd. 1: Esiajalugu ja Muistne vabadusvõitlus / Ed. Moora, Harri; Kruus, Hans. Tartu: Eesti Kirjanduse Selts, 1935. 376 lk.

Eesti NSV ajaloo lugemik. Kd. 1 / Ed. Kahk, Juhan; Vassar, Artur. Tallinn: Eesti Riiklik Kirjastus, 1960. 476 lk. Eesti NSV ajalugu. Kd. 1: Kõige vanemast ajast XIX sajandi 50-ndate aastateni / Ed. Naan, Gustav; Vassar, Artur. Tallinn: Eesti Riiklik Kirjastus, 1955. 790 lk.

Erelt, Pekka. Surnud luuraja tagasitulek. Spioonilugusid Eestist ja eestlastest. Tallinn: Hea Lugu, 2013. 254 lk. Graham, Robert A. Un agente sovietico in Vaticano. La leggenda di «don» Alessandro Kurtna // Studium. 1981. Vol. 77. P. 11-24.

Götz, Johannes. Das Archiv des livländischen Deutschordenszweiges. Eine archivgeschichtliche Untersuchung // Die Kirche im mittelalterlichen Livland / Ed. Biskup, Radosław; et al. Toruń: Wydawnictwo Naukowe Uniwersytetu Mikołaja Kopernika, 2019. P. 9-77.

Heinrici Chronicon Livoniae / Ed. Arbusow, Leonid; Bauer, Albert. Hannover: Hahn, 1955. 255 p.

Helme, Mart. Lembitu. Eesti kroonimata kuningas. Tallinn: Kunst, 2010. 199 lk.

Hindrey, Karl August. Loojak II: Lembitu. Tartu: Noor-Eesti, 1938. 197 lk.

Hirvesoo, Avo. Esimese rahvusooperi tulek meie lavale // Teater, Muusika, Kino. 1986. Nr 8. Lk. 69-75.

Jensen, Carsten Selch. Appropriating History. Remembering the Crusades in Latvia and Estonia // Remembering the Crusades and Crusading / Ed. Cassidy-Welch, Megan. London: Routledge, 2017. P. 231-245. Kalda, Maie. Lembitu kuldne karikas // Looming. 2003. Nr 12. Lk. 1882-1894.

Kaljundi, Linda. Malev // Forschungen zur baltischen Geschichte. 2007. Bd 2. S. 219-225.

Kaljundi, Linda; Klavinš, Kaspars. The Chronicler and the Modern World: Henry of Livonia and the Baltic Crusades in the Enlightenment and National Traditions // Crusading and Chronicle Writing on the Medieval Baltic Frontier. A Companion to the Chronicle of Henry of Livonia / Ed. Tamm, Marek; Kaljundi, Linda; Jensen, Carsten Selch. Farnham: Ashgate, 2011. P. 409-456.

Kaljundi, Linda; Kreem, Tiina-Mall. Ajalugu pildis — pilt ajaloos. Rahvuslik ja rahvusülene minevik eesti kunstis. Tallinn: Eesti Kunstimuuseum, 2018. 368 lk. 
Kivimäe, Jüri. Aleksander Kurtna ja Eesti Teaduste Akadeemia // 50 aastat Eesti Teaduste Akadeemiat / Ed. Köörna, Arno; et al. Tallinn: Eesti Teaduste Akadeemia, 1989. Lk. 187-190.

Kivirähk, Andrus. Rehepapp ehk november. Tallinn: Varrak, 2006. 199 lk.

Kreutzwald, Friedrich Reinhold. Lembitu. Kreutzwaldi usulis-filosoofiline maailmavaade. Friedrich Reinhold Kreutzwald 200 / Ed. Sutrop, Urmas. Tallinn: Eesti Keele Sihtasutus, 2003. 541 lk.

Mazierska, Ewa. Postsotsialistlik Eesti filmikunst kui rahvusülene kino // Kunstiteaduslikke Uurimusi. 2011.

Nr 3-4. Lk. 166-191.

Metsanurk, Mait. Ümera jõel. Tallinn: Eesti Päevaleht, 2008. $351 \mathrm{lk}$.

Misāns, Ilgvars. «Wir waren immer ein Kriegervolk». Die Darstellung der ostbaltischen Kreuzzüge in der lettischen Geschichtsschreibung // Lippe und Livland. Mittelalterliche Herrschaftsbildung im Zeichen der Rose / Ed. Prieur, Jutta. Bielefeld: Verlag für Regionalgeschichte, 2008. S. 185-207.

Oad, Kristjan. Lembitu. Juhtimiskunsti meistriklass vastsel Maarjamaal // Acta Historica Tallinnensia. 2017. Kd. 23. Lk. 26-48.

Panso, Voldemar. Portreed minus ja minu ümber. Tallinn: Eesti Raamat, 1975. $292 \mathrm{lk}$.

Pillak, Peep. Voldemar Miller 90 // Tuna. Ajalookultuuri ajakiri. 2001. Nr 2. Lk. 121-128.

Rajandi, Edgar. Raamat nimedest. Tallinn: Eesti Raamat, 1966. 247 lk.

Schmitz-Esser, Romedio. Der Leichnam im Mittelalter. Einbalsamierung, Verbrennung und die kulturelle Konstruktion des Körpers. Ostfildern: Thorbecke, 2016. 763 s.

Schütz, Eevi. Alma Kurtna. Unustamatu lauluõpetaja. Tartu: Ilmamaa, 2018. 198 lk.

Selart, Anti. Historical Legitimacy and Crusade in Livonia // Crusading on the Edge. Ideas and Practice of Crusading in Iberia and the Baltic Region, 1100-1500 / Ed. Nielsen, Torben Kjersgaard; Fonnesberg-Schmidt, Iben. Turnhout: Brepols, 2016. P. 29-54.

Selart, Anti. Muistne vabadusvõitlus // Vikerkaar. 2003. Nr 10-11. Lk. 108-120.

Selart, Anti. 700 Years of Slavery - A View from Estonia // Controversial Histories - Current Views on the Crusades / Ed. Hinz, Felix; Meyer-Hamme, Johannes. London: Routledge, 2021. P. 89-90.

Selart, Anti; Mäesalu, Mihkel. Die estnischen Kopfjäger in Polen. Eine Archivreise // Forschungen zur baltischen Geschichte. 2019. Bd 14. S. 197-205.

Smuul, Juhan. Muhu monoloogid. Polkovniku lesk. Tallinn: Eesti Raamat, 1968. 135 lk.

Tamm, Marek. History as Cultural Memory: Mnemohistory and the Construction of the Estonian Nation // Contested and Shared Places of Memory. History and Politics in North Eastern Europe / Ed. Hackmann, Jörg; Lehti, Marko. London: Routledge, 2020. P. 116-133.

Tarvel, Enn. Estica Vanade Aktide Peaarhiivis Varssavis // Eesti NSV Teaduste Akadeemia Toimetised. Ühiskonnateaduste seeria. 1960. Kd. 9. Lk. 292-304.

Tarvel, Enn. Estonica't Poola arhiivides ja raamatukogudes // Eesti NSV Teaduste Akadeemia Toimetised. Ühiskonnateaduste seeria. 1972. Kd. 21. Lk. 152-162.

Tõnisson, Evald. Eesti muinaslinnad / Ed. Mäesalu, Ain; Valk, Heiki. Tartu: Tartu Ülikool, 2008. 357 lk.

Tõnisson, Evald; et al. Kui Lembitu kutsus... Tallinn: Eesti Raamat, 1968. 96 lk.

Tõnson, Helga. Villem Kapp. Tallinn: Eesti Raamat, 1967. 212 lk.

Information about the article

The research was supported by the Russian Science Foundation, project Nr. 21-48-04402 «Saints and heroes from Christianization to Nationalism: Symbol, Image, Memory (Nord-West Russia, Baltic and Nordic countries)»

Author: Selart, Anti - PhD in History, Professor of Medieval History, University of Tartu, Tartu, Estonia; Visiting Research Fellow, Institute of History, St.-Petersburg State University, St.-Petersburg, Russia, Orc ID 0000-0001-8608-9154; e-mail: anti.selart@ut.ee

Title: Lembitu: A medieval warlord in Estonian culture

Summary: The $13^{\text {th }}$ century was undoubtedly a period of upheaval in Baltic history. From the traditional «Estonian» point of view, between 1208 and 1227 ancient Estonians heroically defended their political and personal freedom and native religion, but unfortunately they had to surrender to German invaders and the Catholic Church. This interpretation was adopted by the Estonian audience by the end of the $19^{\text {th }}$ century. However, there were not many individual historical heroes to find in medieval history who could fit the national narrative. The $13^{\text {th }}$-century sources mention very few Estonians by their names. There is one exception: Lembitu, the leader of Sakala province. In 1217 he was killed in battle; his head was cut off and taken away by crusaders. Numerous artistic presentations popularised the person of Lembitu in the $19^{\text {th }}$ and $20^{\text {th }}$ century and shaped the public image 
of Lembitu as a king-like leader of the resistance in the name of freedom and independence. At the same time, in the early 2000s parallelly an ironic or critical attitude towards traditional presentations of the medieval warlord developed. A new turn in the presentations of Lembitu in Estonian media happened in the 2010s. The topic then became connected to the question of the fate of the skull of the medieval warlord. In Estonia in the 1960s, a report began to circulate that somewhere in Poland the head of Lembitu still existed. The Estonian Ministry of Culture initiated in 2014 contact between the Estonian and Polish ministries of culture, which resulted in some investigations in Polish museums with the aim of locating the artefact. The initiative was renewed in 2017, and in 2018-2019 the Estonian Ministry of Culture funded the research of the sources of Estonian history in Poland. Although the aim of the research in Poland was defined broadly and had real scholarly results, for the media and public audience it was definitely the project «searching for the skull of Lembitu». The public need for a historical hero, local patriotism combined with tourism marketing, and at least during the last decades the playful handling of history or historical stereotypes shape in combination the presentations of Lembitu in Estonian media and culture today.

Keywords: medievalism, Lembitu, medieval Livonia, Estonian historiography, historical imagology, cultural studies, medieval studies

\section{References:}

Alvarez, David; Graham Robert A. Nothing sacred. Nazi espionage against the Vatican 1939-1945. London: Frank Cass Publ., 2003. 190 p.

Alvarez, David. Spies in the Vatican. Espionage and Intrigue from Napoleon to the Holocaust. Lawrence, KS: University Press of Kansas, 2002. 341 p.

Dobrovolskaya, Yuliya Abramovna. Post Scriptum: Vmesto memuarov [Post scriptum: Instead of memoirs]. St. Petersburg: Aletheia Publ., 2006. 316 p. (in Russian).

Dunn, Steve R. Battle in the Baltic. The Royal Navy and the Fight to Save Estonia \& Latvia 1918-20. Barnsley: Seaforth Publ., 2020. 304 p.

Erelt, Pekka. Surnud luuraja tagasitulek. Spioonilugusid Eestist ja eestlastest [The return of dead spy. Spy stories about Estonia and Estonians]. Tallinn: Hea Lugu Publ., 2013. 254 p. (in Estonian).

Graham, Robert A. Un agente sovietico in Vaticano. La leggenda di «don» Alessandro Kurtna [A Soviet agent in Vatican. The legend of "don" Aleksander Kurtna], in Studium. 1981. Vol. 77. Pp. 11-24. (in Italian). Götz, Johannes. Das Archiv des livländischen Deutschordenszweiges. Eine archivgeschichtliche Untersuchung [The archive of the Livonian branch of the Teutonic Order. A study on archival history], in Biskup, Radosław; et al. (eds). Die Kirche im mittelalterlichen Livland. Torun: Wydawnictwo Naukowe Uniwersytetu Mikołaja Kopernika Publ., 2019. Pp. 9-77. (in German).

Helme, Mart. Lembitu. Eesti kroonimata kuningas [Lembitu. The uncrowned king of Estonia]. Tallinn: Kunst Publ., 2010. 199 p. (in Estonian).

Hirvesoo, Avo. Esimese rahvusooperi tulek meie lavale [The first national opera on our stage], in Teater, Muusika, Kino. 1986. Nr 8. Pp. 69-75. (in Estonian).

Jensen, Carsten Selch. Appropriating History. Remembering the Crusades in Latvia and Estonia, in Cassidy-Welch, Megan (ed.). Remembering the Crusades and Crusading. London: Routledge Publ., 2017. Pp. 231-245.

Kahk, Juhan; Vassar, Artur (eds). Eesti NSV ajaloo lugemik. Kd. 1 [Reader in the history of the Estonian SSR. Vol. 1]. Tallinn: Eesti Riiklik Kirjastus Publ., 1960. 476 p. (in Estonian).

Kalda, Maie. Lembitu kuldne karikas [The golden chalice of Lembitu], in Looming. 2003. Nr 12. Pp. 1882-1894. (in Estonian).

Kaljundi, Linda. Malev [Men at Arms], in Forschungen zur baltischen Geschichte. 2007. Vol. 2. Pp. 219-225. (in German).

Kaljundi, Linda; Klavinš, Kaspars. The Chronicler and the Modern World: Henry of Livonia and the Baltic Crusades in the Enlightenment and National Traditions, in Tamm, Marek; Kaljundi, Linda; Jensen, Carsten Selch (eds). Crusading and Chronicle Writing on the Medieval Baltic Frontier. A Companion to the Chronicle of Henry of Livonia. Farnham: Ashgate Publ., 2011. Pp. 409-456.

Kaljundi, Linda; Kreem, Tiina-Mall. Ajalugu pildis — pilt ajaloos. Rahvuslik ja rahvusülene minevik eesti kunstis [History in pictures-a picture of history: National and Transnational Past in Estonian Art]. Tallinn: Eesti Kunstimuuseum Publ., 2018. 368 p. (in Estonian).

Kivimäe, Jüri. Aleksander Kurtna ja Eesti Teaduste Akadeemia [Aleksander Kurtna and Estonian Academy of Sciences], in Köörna, Arno; et al. (eds). 50 aastat Eesti Teaduste Akadeemiat. Tallinn: Eesti Teaduste Akadeemia Publ., 1989. Pp. 187-190. (in Estonian). 
Kivirähk, Andrus. Rehepapp ehk November. Tallinn: Varrak Publ., 2006. 199 p. (in Estonian).

Kreutzwald, Friedrich Reinhold. Lembitu. Kreutzwaldi usulis-filosoofiline maailmavaade. Friedrich Reinhold Kreutzwald 200 [Lembitu. The religious and philosophical ideology of Kreutzwald. Friedrich Reinhold Kreutzwald 200]. Ed. by Sutrop, Urmas. Tallinn: Eesti Keele Sihtasutus Publ., 2003. 541 p. (in Estonian).

Mazierska, Ewa. Postsotsialistlik Eesti filmikunst kui rahvusülene kino [Post-socialist Estonian cinema as transnational cinema], in Kunstiteaduslikke Uurimusi. 2011. Nr 3-4. Pp. 166-191. (in Estonian).

Metsanurk, Mait. Ümera jõel [On the Ümera River]. Tallinn: Eesti Päevaleht Publ., 2008. 351 p. (in Estonian). Misāns, Ilgvars. «Wir waren immer ein Kriegervolk». Die Darstellung der ostbaltischen Kreuzzüge in der lettischen Geschichtsschreibung [We were always a nation of warriors". The presentation of the Baltic Crusades in the Latvian History-Writing], in Prieur, Jutta (ed.). Lippe und Livland. Mittelalterliche Herrschaftsbildung im Zeichen der Rose. Bielefeld: Verlag für Regionalgeschichte Publ., 2008. Pp. 185-207. (in German).

Naan, Gustav; Vassar, Artur (eds). Eesti NSV ajalugu. Kd. 1: Kõige vanemast ajast XIX sajandi 50-ndate aastateni [The History of the Estonian SSR. Vol. 1: From the most ancient period to the 1850s]. Tallinn: Eesti Riiklik Kirjastus Publ., 1955. 790 p. (in Estonian).

Oad, Kristjan. Lembitu. Juhtimiskunsti meistriklass vastsel Maarjamaal [Lembitu. Masterful leadership in nascent Mary's land], in Acta Historica Tallinnensia. 2017. Kd. 23. Pp. 26-48. (in Estonian).

Panso, Voldemar. Portreed minus ja minu ümber [Portraits in and around me]. Tallinn: Eesti Raamat Publ., 1975. 292 p. (in Estonian).

Pillak, Peep. Voldemar Miller 90 [Voldemar Miller 90], in Tuna. Ajalookultuuri ajakiri. 2001. Nr 2. Pp. 121-128. (in Estonian).

Rajandi, Edgar. Raamat nimedest [The book of names]. Tallinn: Eesti Raamat Publ., 1966. 247 p. (in Estonian). Schmitz-Esser, Romedio. Der Leichnam im Mittelalter. Einbalsamierung, Verbrennung und die kulturelle Konstruktion des Körpers [The Corpse in the Middle Ages: Embalming, Cremating, and the Cultural Construction of the Dead Body]. Ostfildern: Thorbecke Publ., 2016. 763 p. (in German).

Schütz, Eevi. Alma Kurtna. Unustamatu lauluõpetaja [Alma Kurtna. Unforgettable singing teacher]. Tartu: Ilmamaa Publ., 2018. 198 p. (in Estonian).

Selart, Anti. Historical Legitimacy and Crusade in Livonia, in Nielsen, Torben Kjersgaard; FonnesbergSchmidt, Iben (eds). Crusading on the Edge. Ideas and Practice of Crusading in Iberia and the Baltic Region, 1100-1500. Turnhout: Brepols Publ., 2016. Pp. 29-54.

Selart, Anti. Muistne vabadusvõitlus [The Ancient Struggle for Freedom], in Vikerkaar. 2003. Nr 10-11. Pp. 108-120. (in Estonian).

Selart, Anti. 700 Years of Slavery - A View from Estonia, in Hinz, Felix; Meyer-Hamme, Johannes (eds). Controversial Histories - Current Views on the Crusades. London: Routledge Publ., 2021. Pp. 89-90.

Selart, Anti; Mäesalu, Mihkel. Die estnischen Kopfjäger in Polen. Eine Archivreise [The Estonian headhunters in Poland. An archival trip], in Forschungen zur baltischen Geschichte. 2019. Bd 14. Pp. 197-205. (in German). Smuul, Juhan. Muhu monoloogid. Polkovniku lesk [The monologues of Muhu Island. The Colonel's Widow]. Tallinn: Eesti Raamat Publ., 1968. 135 p. (in Estonian).

Tamm, Marek. History as Cultural Memory: Mnemohistory and the Construction of the Estonian Nation, in Hackmann, Jörg; Lehti, Marko (eds). Contested and Shared Places of Memory. History and Politics in North Eastern Europe. London: Routledge Publ., 2020. Pp. 116-133.

Tamm, Marek; Kaljundi, Linda; Jensen, Carsten Selch (eds). Crusading and Chronicle Writing on the Medieval Baltic Frontier. A Companion to the Chronicle of Henry of Livonia. Farnham: Ashgate Publ., 2011. 487 p.

Tarvel, Enn. Estica Vanade Aktide Peaarhiivis Varssavis [Estica in the Central Archive of Historical Records in Warsaw], in Eesti NSV Teaduste Akadeemia Toimetised. Ühiskonnateaduste seeria. 1960. Kd. 9. Pp. 292-304. (in Estonian).

Tarvel, Enn. Estonica't Poola arhiivides ja raamatukogudes [Estonica in Polish archives and libraries], in Eesti NSV Teaduste Akadeemia Toimetised. Ühiskonnateaduste seeria. 1972. Kd. 21. Pp. 152-162. (in Estonian). Tõnisson, Evald. Eesti muinaslinnad [Estonian strongholds]. Ed. by Mäesalu, Ain; Valk, Heiki. Tartu: Tartu Ülikool Publ., 2008. 357 p. (in Estonian).

Tõnisson, Evald; et al. Kui Lembitu kutsus... [When Lembitu invited to...]. Tallinn: Eesti Raamat Publ., 1968. 96 p. (in Estonian).

Tõnson, Helga. Villem Kapp. Tallinn: Eesti Raamat Publ., 1967. 212 p. (in Estonian). 